O.A. Plakhtii ${ }^{1}$, Cand. Sc. (Tech.), orcid.org/0000-0002-1535-8991, V.P. Nerubatskyi², Cand. Sc. (Tech.), orcid.org/0000-0002-4309-601X, D. A. Hordiienko ${ }^{3}$, orcid.org/0000-0002-0347-5656, V.R. Tsybulnyk ${ }^{2}$, orcid.org/0000-0002-9895-6662
1 - Limited Liability Company "VO OVEN", Kharkiv, Ukraine,e-mail: a.plakhtiy1989@gmail.com

2 - Ukrainian State University of railway transport, Kharkiv, Ukraine, e-mail: NVP9@i.ua; naytus2244@gmail.com

3 - Private JSC "ELAKS", Kharkiv, Ukraine, e-mail: D.Hordiienko@i.ua

\title{
ANALYSIS OF THE ENERGY EFFICIENCY OF A TWO-LEVEL VOLTAGE SOURCE INVERTER IN THE OVERMODULATION MODE
}

Purpose. Increasing the output power and ensuring maximum sinusoidality of output current in a two-level voltage source inverter by implementing the overmodulation mode.

Methodology. Simulation in Matlab/Simulink environment of voltage source inverter in the overmodulation mode. Mathematical apparatus of Fourier analysis of the output current spectrum.

Findings. Modeling of the voltage source inverter in the overmodulation mode allowed obtaining a number of dependencies:

- the dependence of the VSI output power on the modulation coefficient k;

- the dependence of the total harmonic distortion of the output current and output voltage on the modulation coefficient;

- the dependence of the total harmonic distortion of the input current in VSI on the modulation coefficient.

Originality. It is established that the overmodulation mode in the voltage source inverter can significantly increase the output power and improve the sinusoidality of output voltage and output current. It is established that the dependence of the total harmonic distortion of the output current has an extremum that causes the point of maximum sinusoidality.

Practical value. The use of the overmodulation mode in a two-level voltage source inverter will ensure maximum sinusoidality of output current and minimize additional power losses in the load from higher harmonics. In addition, the overmodulation mode will significantly reduce the level of emission of higher harmonics of current into the supply network. Practical application of overmodulation mode is performed in frequency converters of the company "VO OVEN".

Keywords: autonomous voltage inverter, harmonics, dynamic power losses, modulation coefficient, overmodulation, energy efficiency

Introduction. Voltage source inverter (VSI) is one of the most common types of power semiconductor converters, which is used in various industries.

An urgent task is a comprehensive improvement of energy efficiency of VSI, including:

- efficiency, depending on the static and dynamic power losses in the IGBTs, as well as additional power losses associated with the resistance of conductors and power of control system;

- sinusoidality of output current of the VSI, on which the additional losses in the VSI load depend (the amount of additional losses in induction motors from the higher harmonic current according to research $[1,2]$ constitute $8-17 \%$ of the value of total power loss);

- total harmonic distortion and the spectrum of harmonics of the input current, on which the additional losses in the power supply lines depend [3, 4].

Literature review. The above VSI energy efficiency indicators are largely dependent on the modulation algorithm chosen. The most commonly used in VSI are classical sinusoidal pulse width modulation and single modulation. The advantage of PWM over single modulation is the ability to control the amplitude of the first harmonic of the output current, which is necessary for both scalar and vector control of the asynchronous electric drive [5]. At the same time, the disadvantage of PWM is the lower output power, as well as the need for a higher switching frequency of power switches, which causes higher dynamic power losses [6, 7].

To obtain improved energy performance of VSI, improved algorithms are implemented, for example, quasi-sinusoidal output voltage with trapezoidal PWM [8, 9]. However, the disadvantage of this method is the lack of control of the output voltage amplitude.

To reduce the emission of higher harmonics of the input current, it is advisable to use the interleaving mode [10, 11]. However, this method is possible only when several inverters are connected in parallel.

(C) Plakhtii O.A., Nerubatskyi V.P., Hordiienko D. A., Tsybulnyk V. R., 2019
Another promising method for increasing the energy efficiency of the voltage source inverter is the use of the overmodulation algorithm in PWM [12, 13]. Overmodulation is a modulation mode in which the peak value of the job signal exceeds the level required to provide $100 \%$ modulation, with the modulation coefficient $\mathrm{k}$ exceeding one unit. This mode allows improving a number of energy parameters of VSI, as well as regulating the amplitude of the output voltage.

$$
k=\frac{\text { Amod }}{\text { Acur }},
$$

where $k$ is the modulation coefficient; Amod is the amplitude of the modulated signal of the task; Acur is the amplitude of the carrier signal.

However, the underlying energy dependence VSI in the overmodulation mode has not been studied, which made the subject of this publication.

Purpose. The purpose of the study is to determine the main energy characteristics of VSI in the overmodulation mode, namely:

- dependence of the output power of VSI on the modulation coefficient;

- dependence of the harmonic distortion index of the output current on the modulation coefficient;

- dependence of the harmonic distortion index of the input current on the modulation coefficient;

- defining dependencies of power losses in the IGBTs on modulation coefficient for the overmodulation mode.

The results of the study of energy processes in the voltage source inverters with sinusoidal PWM in the overmodulation mode. To study the energy characteristics of VSI in the overmodulation mode in the Matlab program, a simulation model was developed. The simulation was performed with the following parameters: power voltage: $3 \mathrm{kV}$; inductance input filter $1 \mathrm{mH}$, the capacitance of the input filter $2 \mathrm{MF}$; inductance load $4 \mathrm{mH}$, load impedance $2 \mathrm{Ohms}$, frequency of the first harmonic of the output voltage $50 \mathrm{~Hz}$, the frequency of the 
reference signal in PWM is $1 \mathrm{kHz}$. A simulation model of the voltage source inverter with the control systems under study is shown in Fig. 1.

In the PWM overmodulation mode, the amplitude of the sinusoidal reference signal is intentionally set higher than the amplitude of the carrier saw-tooth signal (Fig. 2), while the modulation coefficient $\mathrm{k}$ takes a value higher than one unit (Fig. 3).

In the overmodulation mode in VSI under the same load and power experience the following results occur:

- the amplitude of the output voltage and output current increase;

- sinusoidality of output voltage and output current increases;

- dynamic power losses in the IGBTs reduce;

- the index of harmonic distortion of the input current reduces.

The output voltage forms of VSI at modulation coefficients $k=1$ and at $k=2$ are shown in Fig. 4 .

As shown in Fig. 4, by increasing the modulation coefficient $\mathrm{k}$ above one unit, the form of output voltage of VSI tends to the output voltage form under 180-degree control. At the same time, with an increase in the value of the modulation

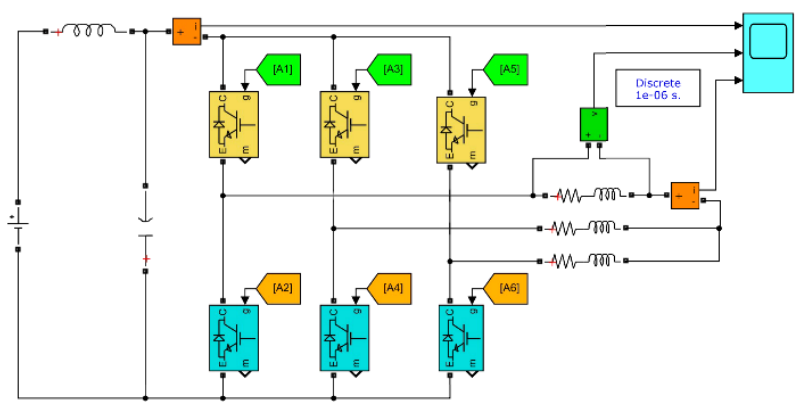

Fig. 1. The simulation model of a two-level voltage source inverter
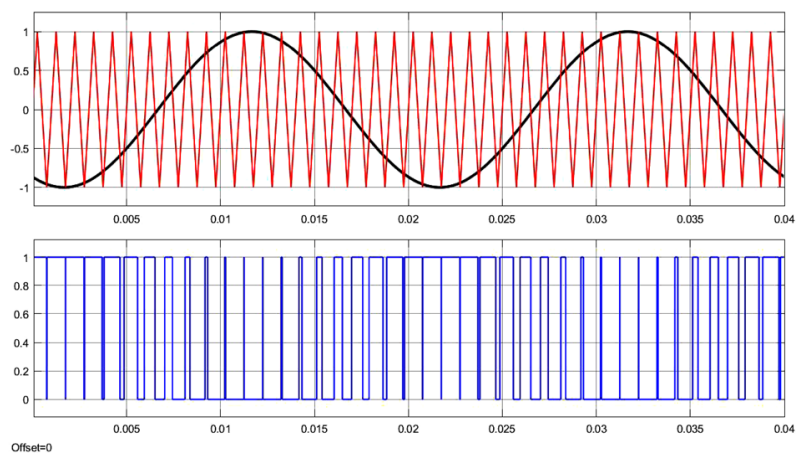

Fig. 2. Pulse width modulation in the sine PWM at $k=1$
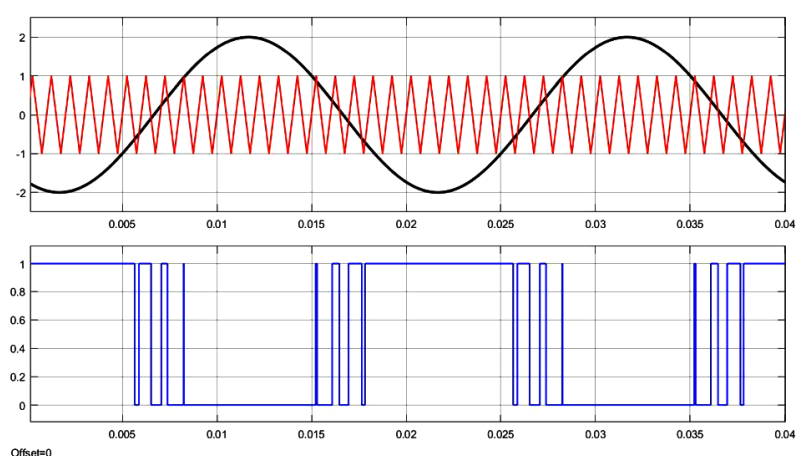

Fig. 3. Pulse width modulation in the overmodulation at $k=2$

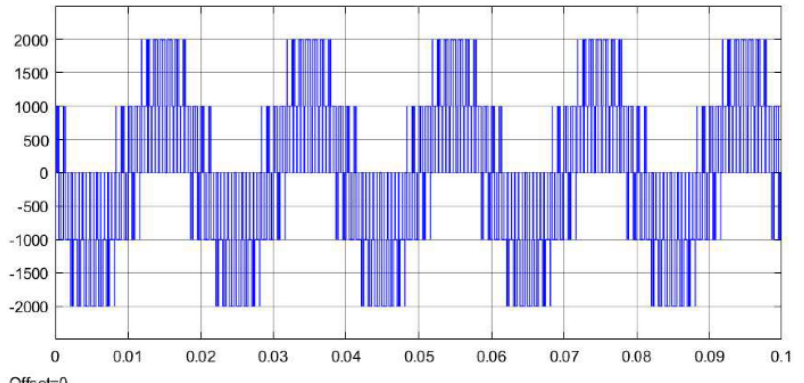

$a$

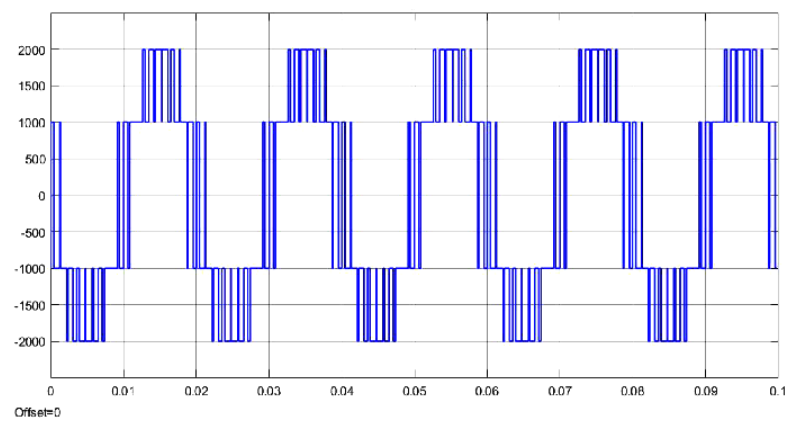

Fig. 4. Form of output voltage of VSI:

$a-a t k=1 ; b-a t k=2$

coefficient $\mathrm{km}$ above the amplitude unit of the first harmonics of the output voltage and output current, they will exponentially tend to the values at 180 -degree control.

The dependence of the amplitude of the first harmonic of the output current of VSI on the value of the modulation coefficient is shown in Fig. 5.

The dependence of the output power in one phase of VSI on the modulation coefficient is shown in Fig. 6.

Thus:

- the overmodulation mode allows increasing the output power of VSI;

- the dependence of the amplitude of the first harmonic output current and output power (Figs. 5, 6) in the overmodulation mode has considerable nonlinearity when $k>1$.

The analysis of the parameters of power quality of VSI in the overmodulation mode. The overmodulation mode has a positive effect not only on the output power of the VSI, but also on the power quality parameters $[14,15]$. In the overmodulation mode, sinusoidality of the output voltage and output current increases. The obtained dependence of the total harmonic distortion (THD) of the output voltage on the modulation coefficient $\mathrm{k}$ is shown in Fig. 7, $a$. As the value of the modulation coefficient $\mathrm{k}$ increases, the value of the THD of the output voltage will decline exponentially to the value of the total harmonic distortion in the single modulation mode, i.e. to the value of $31.09 \%$.

The dependence of the total harmonic distortion of the output current in VSI on the modulation coefficient is shown in Fig. 8.

As shown in Fig. 8, the THD of the output current is reduced to a value of $11.8 \%$ at $k=2.1$ and then begins to grow. This point is important based on the minimization of additional power losses in the asynchronous motor from higher harmonics.

The subsequent increase in the THD of the output current above $k=2.1$ is explained by the fact that when the modulation coefficient increases, the content of the fifth and seventh harmonics in the output voltage and, accordingly, in the output current increases. Thus, it can be concluded that the use of the overmodulation mode is advisable to the value of the modula- 


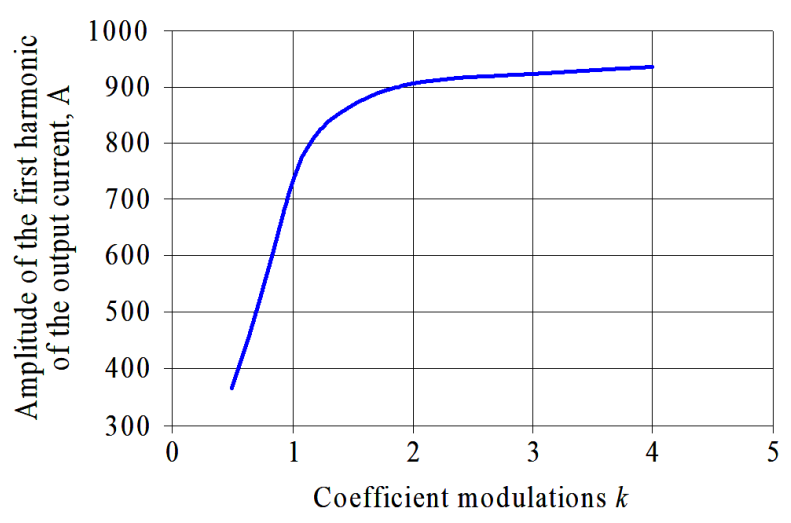

Fig. 5. Dependence of the amplitude of the first harmonic of the output current on the modulation coefficient $k$

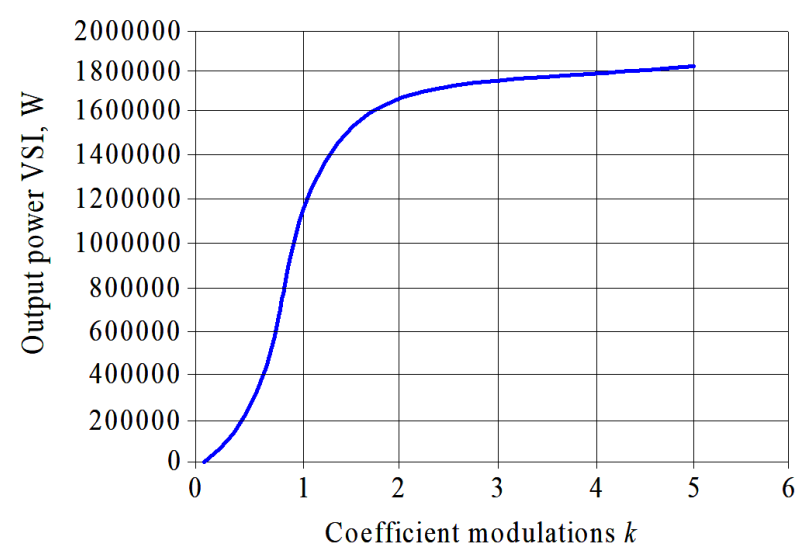

Fig. 6. The dependence of the output power in one phase of VSI on the modulation coefficient

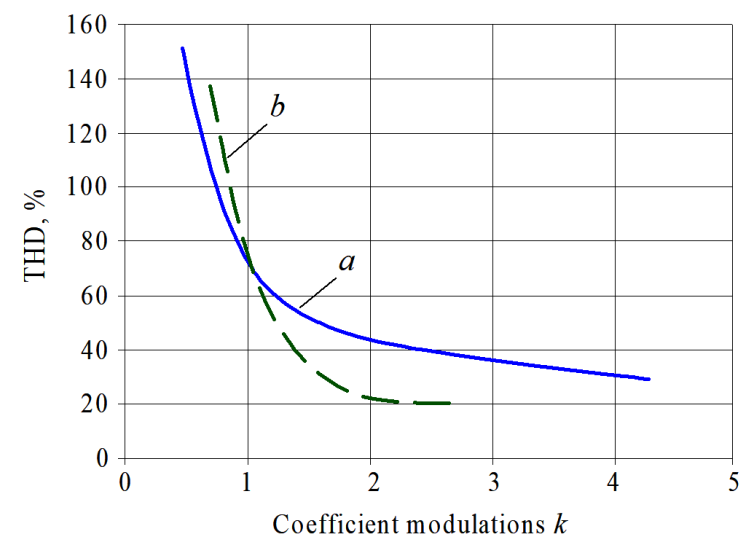

Fig. 7. The dependence of the THD:

$a$ - of the output voltage on the modulation coefficient; $b$ - of the input current of VSI on the modulation coefficient

tion coefficient $k<2.1$, after which there is a deterioration in the sinusoidal output current.

Another advantage of the overmodulation mode is reduction of the input current ripple, which leads to improved electromagnetic compatibility of VSI with the supply network. The dependence of the total harmonic distortion of the input current of VSI on the modulation coefficient is shown in Fig. 7, $b$.

Results of Fourier analysis of the output voltage, output current and input current of VSI at $k=1$ and in the overmodulation mode at $k=2.1$ are shown in Table 1 .

The definition of static and dynamic power losses of power switches in the overmodulation mode. In the overmodulation

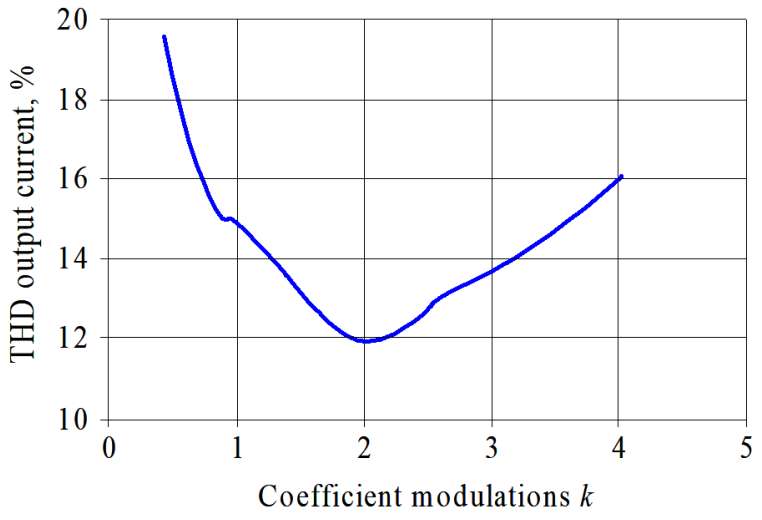

Fig. 8. The dependence of the total harmonic distortion of the output current from the modulation coefficient $k$

Table

Energy efficiency parameters of modulation algorithms in two-level VSI

\begin{tabular}{|l|c|c|}
\hline \multicolumn{1}{|c|}{ Energy performance of VSI } & PWM at $\mathrm{k}=1$ & PWM at k=2.1 \\
\hline PWM frequency, Hz & 1000 & 1000 \\
\hline $\begin{array}{l}\text { Amplitude of the first harmonic } \\
\text { of the output voltage, V }\end{array}$ & 1436 & 1825 \\
\hline $\begin{array}{l}\text { Amplitude of the first harmonic } \\
\text { of the output current, A }\end{array}$ & 709.7 & 901.6 \\
\hline $\begin{array}{l}\text { Full power in one phase VSI, } \\
\text { kVA }\end{array}$ & 1186.6 & 1645.4 \\
\hline THD of the output voltage, $\%$ & 67.39 & 44.5 \\
\hline THD of output current, \% & 14.92 & 11.93 \\
\hline THD of input current, \% & 70.13 & 21.49 \\
\hline Static power loss in IGBT, W & 702 & 924.44 \\
\hline $\begin{array}{l}\text { Dynamic power losses in } \\
\text { IGBT, W }\end{array}$ & 3091 & 1241 \\
\hline Total power losses in IGBT, W & 3793 & 2165.4 \\
\hline
\end{tabular}

mode, time intervals develop in which the sinusoidal reference signal is above a sawtooth waveform [16]. In these time intervals there is no switching in IGBT switch, which leads to a decrease in the number of switching power switches, and, thus, reduces dynamic losses [17, 18].

Calculation of static and dynamic power losses of power switches for the considered modulation algorithms was carried out for IGBT-modules of the $45^{\text {th }}$ class type CM1200HG-90R with a rated current of 1200 A manufactured by Mitsubishi Electric. The calculation was performed in a specialized program MelcoSim. The dependence of the power losses in the power IGBT type CM1200HG-90R at a voltage of $3 \mathrm{kV}$ DC link and the value of the output current $710 \mathrm{~A}$ on the modulation coefficient $k$ is shown in Fig. 9.

Summary comparative results of calculations and modeling of the energy performance of VSI with classical modulation at $k=1$ and the overmodulation mode $k=2.1$ are given in Table.

Conclusions. The overmodulation mode compared to classical sinusoidal PWM under the same load parameters VSI can significantly improve the energy performance of the VSI, namely:

- increase the output power of VSI;

- reduce the values of the total harmonic distortion of the output voltage, output current and input current VSI;

- reduce dynamic power losses of IGBT.

For the overmodulation mode in the VSI the following dependencies are defined: 


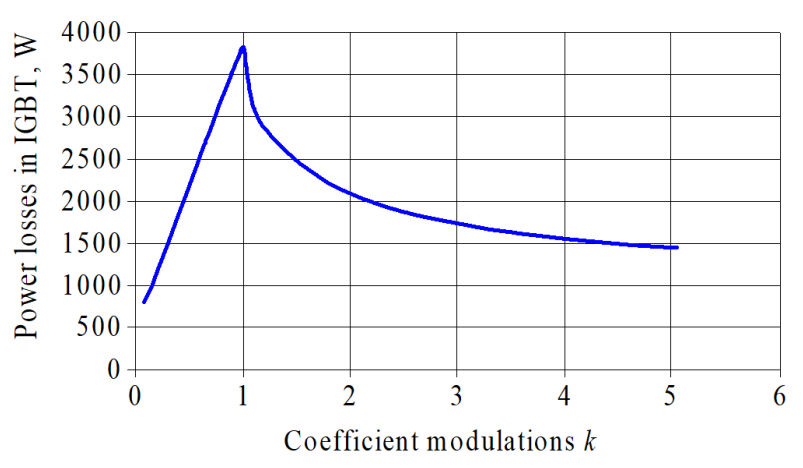

Fig. 9. The dependence of the power losses in the IGBT CM1200HG-90R on the modulation coefficient

- dependence of the total harmonic distortion of the output voltage, output current and input current on the modulation coefficient;

- dependence of the amplitude of the output current and output power on the modulation coefficient.

It is established that in the overmodulation mode the dependence of the total harmonic distortion of the output current VSI on the modulation coefficient has an extreme value, which causes a minimum value of the total harmonic distortion, which is important to reduce additional losses in the asynchronous motor from higher harmonics.

\section{References.}

1. Petrenko, A. N., Tanyansky, V. I., \& Petrenko, N. Ya. (2012). Additional power losses of a frequency-controlled asynchronous motor from higher voltage harmonics. Electrical Engineering and Electromechanics, (5), 34-35.

2. Kazakov, Yu. B., \& Shvetsov, N. K. (2015). Calculated analysis of losses in steel of asynchronous motors when powered by frequency converters with non-sinusoidal output voltage. Messenger IHEU, 5, 1-5.

3. Plakhtii, O., Nerubatskyi, V., Ryshchenko, I., Zinchenko, O., Tykhonravov, S., \& Hordiienko, D. (2019). Determining additional power losses in the electricity supply systems due to current's higher harmonics. Eastern-European Journal of Enterprise Technologies, 1(8(97)), 6-13. DOI: 10.15587/17294061.2019.155672.

4. Arcega, F. J., \& Pardina, A. (2014). Study of harmonics thermal effect in conductors produced by skin effect, IEEE Latin America Transactions, 12(8), 1488-1495. DOI: 10.1109/ TLA.2014.7014518.

5. Vasil'ev, B. Yu., \& Dobush, V.S. (2014). Effective control algorithms semiconductor converters in asynchronous electric drive. Electrical Technology, (4), 54-61.

6. Michalsky, V. M. (2013). Means for improving the quality of electricity at the input and output of frequency converters with pulse-width modulation: monograph. Kyiv: Institute of Electrodynamics of the National Academy of Sciences of Ukraine.

7. Nerubatskyi, V.P., Plakhtii, O.A., Kavun, V.E., Mashura, A. V., Hordiienko, D. A., \& Tsybulnyk, V. R. (2018). Analysis of indices of energy efficiency of autonomous voltage inverters with various modulation types. Collection of Scientific Works of the Ukrainian State University of Railway Transport, 180, 106-120.

8. Kolosov, V., \& Vasechko, E. (2017). Formation of quasi-sinusoidal voltage in bridge inverters. Vestnik NTU "HPI", 27(1249), 318-323. DOI: 10.20998/2413-4295.2018.26.14.

9. Dias, R. A., Lira, G. R., Costa, E. G., Ferreira, R. S., \& Andrade, A. F. (2018). Skin effect comparative analysis in electric cables using computational simulations: 2018. In Simposio Brasileiro de Sistemas Eletricos (SBSE) (pp. 1-6). DOI: 10.1109/SBSE.2018.8395687.

10. Plakhtii, O.A., \& Nerubatskyi, V.P. (2018). Analyses of energy efficiency of interleaving in active voltage-source recti- fier. In 2018 IEEE $3^{\text {rd }}$ International Conference on Intelligent Energy and Power Systems (IEPS), (pp. 253-258). DOI: 10.1109/IEPS.2018.8559514.

11. Blahnik, V., \& Talla, J. (2016). Single-phase synchronization for traction active rectifier. In 2016 International Conference on Applied Electronics (AE). DOI: 10.1109/ae.2016.7577233. 12. Vasil'ev, B. Yu. (2015). Providing overmodulation mode and increasing energy conversion efficiency in autonomous power inverters of electric drives. Electricity, (6), 47-55.

13. Kostic, D.J., Avramovic, Z.Z., \& Ciric, N.T. (2013). A new approach to theoretical analysis of harmonic content of PWM waveforms of single- and multiple-frequency modulators. IEEE Transactions on Power Electronics, 28(10), 45574567. DOI: 10.1109/TPEL.2012.2232309.

14. Borrega, M., Marroyo, L., Gonzalez, R., Balda, J., \& Agorreta, J. L. (2013). Modeling and control of a master-slave PV inverter with n-paralleled inverters and three-phase threelimb inductors. IEEE Transactions on Power Electronics, 28(6), 2842-2855. DOI: 10.1109/TPEL.2012.2220859.

15. Fomin, O. V., Lovska, A. O., Plakhtii, O.A., \& Nerubatskyi, V. P. (2017). The influence of implementation of circular pipes in load-bearing structures of bodies of freight cars on their physico-mechanical properties. Naukovyi Visnyk Natsionalnoho Hirnychoho Universytetu, 6(162), 89-96.

16. Zhemerov, G. G., Tugay, D. V., \& Titarenko, I. G. (2013). Simulation of AC drives system comprising multilevel inverter. Electrical engineering and electromechanics, (2), 40-47.

17. Lazzarin, T., Bauer, G., \& Barbi, I. (2013). A control strategy for parallel operation of single-phase voltage source inverters: analysis, design and experimental results. IEEE Transactions on Industrial Electronics, 60(6), 2194-2204. DOI: 10.1109/TIE.2012.2193856.

18. Wei, L., Jankovic, Z., Patel, Y. P., \& Hu, J. (2016). Single phase precharge control method for active front end rectifier. In 2016 IEEE Energy Conversion Congress and Exposition (ECCE). DOI: 10.1109/ecce.2016.7855436.

\section{Аналіз енергоефективності дворівневих автономних інверторів напруги в режимі перемодуляції}

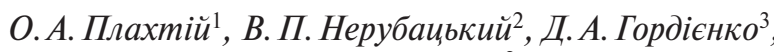 В. Р. Цибульник ${ }^{2}$}

1 - Конструкторське бюро ТОВ „ВО ОВЕН“, м. Харків, Україна, е-mail: a.plakhtiy1989@gmail.com

2 - Український державний університет залізничного транспорту, м. Харків, Україна, e-mail: NVP9@i.ua; naytus2244@gmail.com

3 - ПрАТ „ЕЛАКС“, м. Харків, Україна, е-mail: D.Hordiienko@i.ua

Мета. Підвищення вихідної потужності й забезпечення максимальної синусоїдальності вихідного струму у дворівневому автономному інверторі напруги шляхом реалізації режиму перемодуляції.

Методика. Імітаційне моделювання в середовищі Matlab/Simulink автономного інвертора напруги в режимі перемодуляції. Математичний апарат Фур'є-аналізу спектра вихідного струму.

Результати. Моделювання автономного інвертора напруги в режимі перемодуляції дозволило отримати ряд залежностей:

- залежність вихідної потужності від коефіцієнта модуляції;

- залежності коефіцієнтів гармонічних спотворень вихідного струму й вихідної напруги від коефіцієнта модуляції;

- залежність коефіцієнта гармонічних спотворень вхідного струму від коефіцієнта модуляції. 
Наукова новизна. Встановлено, що режим перемодуляції в автономному інверторі напруги дозволяє у значній мірі підвищити вихідну потужність і поліпшити синусоїдальність вихідної напруги та вихідного струму. Встановлено, що залежність коефіцієнта гармонічних спотворень вихідного струму має екстремум, що зумовлює точку максимальної синусоїдальності.

Практична значимість. Застосування режиму перемодуляції у дворівневому автономному інверторі напруги дозволить забезпечити максимальну синусоїдальність вихідного струму й мінімізувати додаткові втрати в навантаженні від вищих гармонік. Крім цього, режим перемодуляції дозволить значно знизити рівень емісії вищих гармонік струму в мережу живлення. Практичне застосування режиму перемодуляції здійснено в перетворювачах частоти ТОВ „ВО ОВЕН““.

Ключові слова: автономний інвертор напруги, гармоніки, динамічні втрати, коефіцієнт модуляції, перемодуляція, енергоефективність

\section{Анализ энергоэффективности двухуровневых автономных инверторов напряжения в режиме перемодуляции}

\section{А. А. Плахтий', В. П. Нерубацкий², Д. А. Гордиенкоз, В. Р. Цыбульник ${ }^{2}$}

1 - Конструкторское бюро ООО „ВО ОВЕН“, г. Харьков, Украина, e-mail: a.plakhtiy1989@gmail.com

2 - Украинский государственный университет железнодорожного транспорта, г. Харьков, Украина, e-mail: NVP9@i.ua; naytus2244@gmail.com

3 - ЧАО „ЭЛАКС“, г. Харьков, Украина, e-mail: D.Hordiienko@i.ua

Цель. Повышение выходной мощности и обеспечение максимальной синусоидальности выходного тока в двухуровневом автономном инверторе напряжения путём реализации режима перемодуляции.

Методика. Имитационное моделирование в среде Matlab/Simulink автономного инвертора напряжения в режиме перемодуляции. Математический аппарат Фурье-анализа спектра выходного тока.

Результаты. Моделирование автономного инвертора напряжения в режиме перемодуляции позволило получить ряд зависимостей:

- зависимость выходной мощности от коэффициента модуляции;

- зависимости коэффициентов гармонических искажений выходного тока и выходного напряжения от коэффициента модуляции;

- зависимость коэффициента гармонических искажений входного тока от коэффициента модуляции.

Научная новизна. Установлено, что режим перемодуляции в автономном инверторе напряжения позволяет в значительной степени повысить выходную мощность и улучшить синусоидальность выходного напряжения и выходного тока. Установлено, что зависимость коэффициента гармонических искажений выходного тока имеет экстремум, обуславливающий точку максимальной синусоидальности.

Практическая значимость. Применение режима перемодуляции в двухуровневом автономном инверторе напряжения позволит обеспечить максимальную синусоидальность выходного тока и минимизировать дополнительные потери в нагрузке от высших гармоник. Кроме этого, режим перемодуляции позволит значительно снизить уровень эмиссии высших гармоник тока в питающую сеть. Практическое применение режима перемодуляции осуществлено в преобразователях частоты ООО „ВО ОВЕН“.

Ключевые слова: автономный инвертор напряжения, гармоники, динамические потери, коэффициент модуляиии, перемодуляция, энергоэффективность

Рекомендовано до публікації докт. техн. наук О. С. Крашенініним. Дата надходження рукопису 28.07.18. 